\title{
An evaluation of multidrug-resistant Escherichia coli isolates in urinary tract infections from Aguascalientes, Mexico: cross-sectional study
}

Flor Y. Ramírez-Castillo', Adriana C. Moreno-Flores ${ }^{1}$, Francisco J. Avelar-González², Francisco Márquez-Díaz ${ }^{3}$, Josée Harel ${ }^{4}$ and Alma L. Guerrero-Barrera ${ }^{*}$

\begin{abstract}
Background: Uropathogenic Escherichia coli (UPEC) are one of the main bacteria causing urinary tract infections (UTIS). The rates of UPEC with high resistance towards antibiotics and multidrug-resistant bacteria have increased dramatically in recent years and could difficult the treatment.

Methods: The aim of the study was to determine multidrug-resistant bacteria, antibiotic resistance profile, virulence traits, and genetic background of $110 \mathrm{E}$. coli isolated from community (79 isolates) and hospital-acquired (31 isolates) urinary tract infections. The plasmid-mediated quinolone resistance genes presence was also investigated. A subset of 18 isolates with a quinolone-resistance phenotype was examined for common virulence genes encoded in diarrheagenic and extra-intestinal pathogenic E. coli by a specific E. coli microarray.

Results: Female children were the group most affected by UTIs, which were mainly community-acquired. Resistance to trimethoprim-sulfamethoxazole, ampicillin, and ampicillin-sulbactam was most prevalent. A frequent occurrence of resistance toward ciprofloxacin (47.3\%), levofloxacin (43.6\%) and cephalosporins (27.6\%) was observed. In addition, $63 \%$ of the strains were multidrug-resistant (MDR). Almost all the fluoroquinolone (FQ)-resistant strains showed MDRphenotype. Isolates from male patients were associated to FQ-resistant and MDR-phenotype. Moreover, hospitalacquired infections were correlated to third generation cephalosporin and nitrofurantoin resistance and the presence of kpsMTII gene. Overall, fimH (71.8\%) and fyuA (68.2\%), had the highest prevalence as virulence genes among isolates. However, the profile of virulence genes displayed a great diversity, which included the presence of genes related to diarrheagenic E. coli. Out of 110 isolates, 25 isolates (22.7\%) were positive to $9 n r A, 23$ (20.9\%) to qnrB, 7 (6.4\%) to qnrS1, $7(6.4 \%)$ to $\operatorname{aac}\left(6^{\prime}\right) \mid b-c r, 5(4.5 \%)$ to $9 n r D$, and $1(0.9 \%)$ to gnrC genes. A total of $12.7 \%$ of the isolates harbored bla $a_{\text {CTX-M }}$ genes, with bla $a_{\mathrm{CTX}-\mathrm{M}-15}$ being the most prevalent.

Conclusions: Urinary tract infection due to E. coli may be difficult to treat empirically due to high resistance to commonly used antibiotics. Continuous surveillance of multidrug resistant organisms and patterns of drug resistance are needed in order to prevent treatment failure and reduce selective pressure. These findings may help choosing more suitable treatments of UTI patients in this region of Mexico.
\end{abstract}

Keywords: Urinary tract infection, Multidrug-resistant, Fluoroquinolone-resistant, Plasmid-mediated quinolone resistance (PMQR), CTX-M

\footnotetext{
*Correspondence: alguerre@correo.uaa.mx

${ }^{1}$ Laboratorio de Biología Celular y Tisular, Departamento de Morfología, Universidad Autónoma de Aguascalientes, Av. Universidad 940, Col. Cd. Universitaria, 20131 Aguascalientes, Mexico

Full list of author information is available at the end of the article
} 


\section{Background}

Escherichia coli is an important cause of extra-intestinal infections, enteric disease, and systemic infections in humans and animals. Uropathogenic Escherichia coli (UPEC), one of the members of the extra-intestinal pathogenic E. coli (ExPEC) is a predominant pathogen causing urinary tract infections (UTIs) [1]. UPEC is one of the main causes of community (80-90\%) and nosocomialacquired UTIs (30-50\%) [2]. These strains harbor a variety of virulence factors that allow them to establish an infection, including adhesins, toxins, host defense avoidance mechanisms and multiple iron acquisition systems [3].

UTIs are one of the most common bacterial infections worldwide. It has been estimated that 150 million UTIs occur per year worldwide [4]. ExPEC strains are responsible for an estimated 40,000 deaths and at least $\$ 2.6$ billion of expenses in healthcare treatment in the United States alone [5]. In Mexico, 3'648,784 cases were reported on 2015 [6]. Although these infections are treatable, the increasingly accelerated rates or multi-drug resistant organisms (MDRO) lead to complication, treatment failure and increased rates of mortality and morbidity [7].

The enhanced prevalence and global spread of extended-spectrum beta-lactamase (ESBL) genes [8] such as CTX-M enzymes that are associated to multidrug-resistant (MDR) phenotypes and fluoroquinolones resistance, has become a major concern $[9,10]$. Quinolones are broad-spectrum antibiotics and very important in the treatment of a wide range of diseases, especially urinary tract infections. Quinolone resistance is mainly caused by chromosomal mutations in the quinolone resistance-determining region (QRDR) of gyrase ( $g y r A$ and $g y r B$ ) and topoisomerase (parC and parE) genes, but also is caused by plasmid-mediated quinolone resistance (PMQR) which include: the pentapeptide repeat family Qnr proteins (QnrA, QnrB, QnrS, QnrC and QnrD) [11], the variant of the aminoglycoside-acetyltransferase modifying enzyme, AAC $\left(6^{\prime}\right)$-lb-cr [12], and the efflux pumps QepA and OqxAB [13-15]. Although PMQR genes confer only low-level of resistance to quinolones [16] they could spread horizontally among Enterobacteria and facilitate the selection of resistant mutants as well as the selection of additional resistance mechanisms, enabling bacteria to become fully resistant $[8,17]$.

The emergence of MDR E. coli causing urinary tract infections with high virulence potential is alarming. In Mexico, a high rate of resistance against quinolones has been observed in environmental, diarrheagenic [18], and pediatric clinical isolates [19]. MDR phenotype of UPEC has also been shown [20, 21]. However, lack of sufficient data on virulence spectrum and MDR-UPEC isolates from community and hospital infections hinders the infections control and management efforts. The aim of this study was to determine the occurrence of MDR-phenotype, antibiotic resistance profile, virulence traits, and genetic background of $E$. coli isolates from community and hospital-acquired UTIs from Mexico.

\section{Methods}

\section{Escherichia coli isolation}

This study was conducted on a total of one hundred and ten urine cultures collected from patients suspected to have an UTI (urine samples contained bacterial counts to $\geq 10^{5} \mathrm{CFU} / \mathrm{ml}$ ) and sought attention in the Centenario Hospital Miguel Hidalgo, in Aguascalientes, Mexico during the period June to November 2012. Patient's ages ranged from neonatal to 91 years. Only one nonduplicated $E$. coli isolate per culture was considered. Patients from whom E. coli was isolated at least $48 \mathrm{~h}$ after admission were considered to have a hospitalacquired infection, all other infections were considered to be community-acquired [22]. To isolate E. coli, serial decimal dilutions of the sample were prepared in $0.85 \%$ $\mathrm{NaCl}$, and were used to inoculate MacConkey agar plates which were incubated overnight at $37^{\circ} \mathrm{C}$. All the isolates were screened by PCR for the uidA gene as confirmation (Table 1). The E. coli isolates were stored at $-80{ }^{\circ} \mathrm{C}$ in Luria-Bertani broth and 20\% (vol/vol) glycerol.

\section{Antimicrobial susceptibility test}

Susceptibility to antimicrobial agents was determined by the agar dilution method as recommended by the standards of Clinical Laboratory Standards Institute [23]. The following antimicrobial agents were tested: ampicillin, ampicillin-sulbactam, amoxicillin-clavulanic acid, piperacillin-tazobactam, cefazolin, cefotaxime, ceftazidime, ceftriaxone, cefepime, amikacin, gentamicin, tobramycin, netilmicin, imipenem, ertapenem, trimethoprim-sulfamethoxazole, ciprofloxacin, levofloxacin and norfloxacin. E. coli ATCC 25922 was included in each assay as a negative control.

\section{Determination of phylo-groups}

Phylo-grouping was determined by PCR as previously described by Clermont et al. [24]. E. coli strains H10407 (phylo-group A), E22 (phylo-group B1), CFT073 (phylogroup B2), ECOR 70 (phylo-group C), O42 (phylo-group D), EDL933 (phylo-group E) and ECOR 36 (phylo-group F), were taken as positive controls. Water was used as negative control. All strains controls were kindly provided by Laboratoire de référence pour Escherichia coli, EcL, Faculté de Médecine Vétérinaire, Université de Montréal. 
Table 1 Oligonucleotides used in this study

\begin{tabular}{|c|c|c|c|c|}
\hline Oligonucleotide name & Target gene & Oligonucleotide $5^{\prime} \rightarrow 3^{\prime}$ & $\begin{array}{l}\text { Amplification product } \\
\text { (bp) }\end{array}$ & References \\
\hline \multicolumn{5}{|l|}{ E. coli marker } \\
\hline uidA-forward & uidA & ATGTGCTGTGCCTGAACC & 450 & {$[60]$} \\
\hline uidA-reverse & & ATTGTTTGCCTCCCTGCTG & & \\
\hline \multicolumn{5}{|c|}{ Virulence genes for extra-intestinal pathogenic E. coli } \\
\hline papC-forward & papC & GACGGCTGTACTGCAGGGTGTGGCG & 350 & [61] \\
\hline papC-reverse & & ATATCCTTTCTGCAGGGATGCAATA & & \\
\hline SfaSf & sfas & GTGGATACGACGATTACTGTG & 240 & [62] \\
\hline SfaSr & & CCGCCAGCATTCCCTGTATTC & & \\
\hline Afaf & $a f a / d r a$ & GGCAGAGGGCCGGCAACAGGC & 592 & [62] \\
\hline Afar & & CCCGTAACGCGCCAGCATCTC & & \\
\hline FyuAf & fyuA & TGATTAACCCCGCGACGGGAA & 880 & [62] \\
\hline FyuAr & & CGCAGTAGGCACGATGTTGTA & & \\
\hline yfcV-forward & $y f c V$ & ACATGGAGACCACGTTCACC & 292 & [63] \\
\hline yfcV-reverse & & GTAATCTGGAATGTGGTCAGG & & \\
\hline Vat-forward & vat & TCAGGACACGTTCAGGCATTCAGT & 1100 & [63] \\
\hline Vat-reverse & & GGCCAGAACATTTGCTCCCTTGTT & & \\
\hline KpsMllf & kpsMT II & GCGCATTTGCTGATACTGTTG & 272 & {$[62]$} \\
\hline KpsMllr & & CATCCAGACGATAAGCATGAGCA & & \\
\hline \multicolumn{5}{|c|}{ Quinolone resistance genes } \\
\hline gyrA11753 & gyrA & GTATAACGCATTGCCGC & 251 & [64] \\
\hline gyrA12004 & & TGCCAGATGTCCGAGAT & & \\
\hline EC-PAR-A & parC & CTGAATGCCAGCGCCAAATT & 189 & {$[65]$} \\
\hline EC-PAR-B & & GCGAACGATTTCGGATCGTC & & \\
\hline qnrA-forward & qnrA & TCAGCAAGAGGATTTCTCA & 605 & {$[66]$} \\
\hline qnrA-reverse & & GGCAGCACTATTACTCCCA & & \\
\hline qnrB-forward & qnrB & GATCGTGAAAGCCAGAAAGG & 469 & [12] \\
\hline qnrB-reverse & & ACGATGCCTGGTAGTTGTCC & & \\
\hline qnrS-forward & anrs & ACGACATTCGTCAACTGCAA & 417 & [12] \\
\hline qurs-reverse & & TAAATTGGCACCCTGTAGGC & & \\
\hline qnrC-forward & anrC & GGGTTGTACATTTATTGAATC & 447 & {$[64]$} \\
\hline qnrC-reverse & & TCCACTTTACGAGGTTCT & & \\
\hline qnrD-forward & qnrD & CGAGATCAATTTACGGGGAATA & 582 & [27] \\
\hline qurD-reverse & & AACAAGCTGAAGCGCCTG & & \\
\hline qepA-forward & qерA & CTGCAGGTACTGCGTCATG & 403 & {$[67]$} \\
\hline qepA-reverse & & CGTGTTGCTGGAGTTCTTC & & \\
\hline aac-forward & $a c c-\left(6^{\prime}\right)-1 b$ & TTGCGATGCTCTATGAGTGGCTA & 482 & [26] \\
\hline aac-reverse & & CTCGAATGCCTGGCGTGTTT & & \\
\hline \multicolumn{5}{|c|}{ Beta-lactamase resistant genes } \\
\hline blaTEM-forward & $b / a_{\text {TEM }}$ & GAGTATTCAACATTTTCGT & 857 & {$[30]$} \\
\hline blaTEM-reverse & & ACCAATGCTTAATCAGTGA & & \\
\hline blaSHV-forward & $b l a_{\mathrm{SHV}}$ & TCGCCTGTGTATTATCTCCC & 768 & {$[30]$} \\
\hline blaSHV-reverse & & CGCAGATAAATCACCACAATG & & \\
\hline blaOXA-1-forward & $b / a_{\mathrm{OXA}-1}$ & GCAGCGCCAGTGCATCAAC & 198 & [30] \\
\hline blaOXA-1-reverse & & CCGCATCAAATGCCATAAGTG & & \\
\hline blaOXA-7-forward & $b l a_{\mathrm{OXA}-7,-9}$ & AGTTCTCTGCCGAAGCC & 591 & [30] \\
\hline blaOXA-7-reverse & & TCTCAACCCAACCAACCC & & \\
\hline blaPSE-4-forward & $b / a_{\mathrm{PSE}-4}$ & CTGCTCGTATAGGTGTTTCC & 705 & [30] \\
\hline blaPSE-4-reverse & & TCGCATCATTTCGCTCTTC & & \\
\hline
\end{tabular}


Table 1 (continued)

\begin{tabular}{|c|c|c|c|c|}
\hline Oligonucleotide name & Target gene & Oligonucleotide $5^{\prime} \rightarrow 3^{\prime}$ & $\begin{array}{l}\text { Amplification product } \\
\text { (bp) }\end{array}$ & References \\
\hline blaCTX-M-3-f & $b / a_{\text {CTX-M-3 }}$ & AATCACTGCGTCAGTTCAC & 701 & [30] \\
\hline blaCTX-M-3-r & & TTTATCCCCCACAACCCAG & & \\
\hline blaCTX-M-forward & $b l a_{\text {CTX-M }}$ & AAGGCGTTTTGACAGACTATT & 920 & This study \\
\hline blaCTX-M-reverse & & GGTGACGATTTTAGCCGC & & \\
\hline
\end{tabular}

Table 2 PCR control strains used in this study

\begin{tabular}{|c|c|}
\hline Control strain & Positive gene (s) \\
\hline J53pMG252 & gnrA \\
\hline J53pMG298 & $q n r B$ \\
\hline J53pMG306 & anrs \\
\hline Salmonella SA20042859 & $a a c\left(6^{\prime}\right)-1 b$ \\
\hline CFT073 & $\begin{array}{l}\text { uidA, papC, fyuA, } \\
\text { chuA, kpsMTII, } \\
\text { yfcV }\end{array}$ \\
\hline J96 & sfas \\
\hline UTI89 & vat \\
\hline R455 & $b / a_{\mathrm{OXA}-1}$ \\
\hline R6 K & $b l a_{\mathrm{TEM}}$ \\
\hline HB101 & $b l a_{\mathrm{SHV}}$ \\
\hline pMG202 & $b / a_{\mathrm{OXA}-7,-9}$ \\
\hline pMON711 & $b / a_{\mathrm{PSE}-4}$ \\
\hline CCRI-2167 & $b l a_{\text {CTX-M }}$ \\
\hline
\end{tabular}

\section{Detection of virulence factors}

Escherichia coli isolates from urinary tract infections were screened for the presence of commonly detected UPEC virulence genes including: $f y u A$, fimH, sfaS, afa/ dra, papC, agn43, yfcV, vat, hlyA, cnfland kpsMTII. Primers and controls used in this study are listed in Tables 1 and 2.

\section{Characterization of resistance genes and mutations}

Screening for plasmid mediated quinolone resistance (PMQR) genes, including qnrA, qnrB, qnrS, qnrC, qnrD, $q e p A$, and $a c c\left(6^{\prime}\right)-l b$ genes was performed as previously described [13, 25-28]. The qurC, qnrD and $a a c$ (6')-Ib cr variants were identified sequencing the PCR products. The quinolone resistance determining regions (QRDR) of $g y r A$ and parC genes were amplified and sequenced on both strands and predicted peptide sequences were compared to the corresponding gene from the MG1655 genome as described by Namboodiri et al. [29]. Beta-lactams genes detection including $b l a_{\mathrm{TEM}}, b l a_{\mathrm{SHV}}, b l a_{\mathrm{OXA}}$, $b l a_{\mathrm{PSE}}$ and $b l a_{\mathrm{CTX}-\mathrm{M}}$ were carried out by PCR amplification using specific primers [30]. Amplicons from all of the bla $a_{\text {СТХ-M }}$ positive isolates were sequenced. The nucleotide sequences obtained were aligned and further analyzed by comparison to sequences from a catalogue of beta-lactamases (http://www.lahey.org/studies/).

\section{DNA microarray analysis}

Microarray hybridizations were performed using $E$. coli maxivirulence version 3.1 microarray as previously described [31]. It allows the detection of 348 virulence genes and 98 antibiotic resistance genes and variants. DNA extraction and hybridizations were performed as described previously [32]. Each isolate was assigned to a specific $E$. coli pathotype according to its virulence gene profile and based on the classification published in previous papers $[31,33]$.

\section{Statistical analysis}

Categorical variables were compared using Pearson's Chi square or Fisher's exact test as appropriate. Continuous variables were compared using Mann-Whitney $U$ test (STATISTICA V. 10, StatSoft, United States). p values less than 0.05 were considered statistically significant.

\section{Results}

\section{Patient demographics}

During the period of study, females (86 samples, 78.2\%) were the most affected group of patients $(p<0.05)$ as compared to males (24 samples, 21.8\%). Most of the UTIs were detected in community obtained samples (79 samples, 71.8\%). Thirty-one samples were recovered from hospital-acquired infections (28.2\%). E. coli isolated from female patients were correlated with communityacquired UTIs $(p=0.0297)$. No differences among the prevalence of $E$. coli isolated from male patients among community- and hospital-acquired infections were found (54.2\% vs $45.8 \%$, respectively). Maximum number of cases was found in female children in the age group of $2-10$ years (34 samples, $39 \%, p=0.0372$, Table 3 ).

\section{Antibiotic resistance and MDR profiles in $E$. coli isolates}

High frequencies of resistance were observed toward trimethoprim-sulfamethoxazole (72.7\%), ampicillin (70.9\%), ampicillin-sulbactam (55.5\%), piperacillin-tazobactam (55.5\%), ciprofloxacin (47.3\%), and levofloxacin (43.6\%). From the twenty different antibiotic tested, 
Table 3 Patients with urinary tract infections, $\mathbf{n}(\%)$

\begin{tabular}{|c|c|c|c|c|c|c|c|}
\hline Age group & $\begin{array}{l}\text { All patients, } \\
n=110(\%)\end{array}$ & Male, $n=24(\%)$ & Female, $n=86(\%)$ & ${ }^{*} p$ & $\begin{array}{l}\text { Hospital- } \\
\text { acquired, } n=31 \\
\text { (\%) }\end{array}$ & $\begin{array}{l}\text { Community- } \\
\text { acquired, } n=79(\%)\end{array}$ & ${ }^{*} p$ \\
\hline $0-1$ & $17(15.5)$ & $6(25.0)$ & $11(12.8)$ & 0.1434 & $5(16.1)$ & $12(15.2)$ & 0.9024 \\
\hline $2-10$ & $38(34.5)$ & $4(16.7)$ & $34(39.5)$ & 0.0372 & $9(29.0)$ & $29(36.7)$ & 0.4462 \\
\hline $11-20$ & $12(10.9)$ & $1(4.2)$ & $11(12.8)$ & 0.2308 & $2(6.5)$ & $10(12.7)$ & 0.3475 \\
\hline $21-30$ & $7(6.4)$ & $2(8.3)$ & $5(5.8)$ & 0.6548 & $1(3.2)$ & $6(7.6)$ & 0.3983 \\
\hline $31-40$ & $6(5.5)$ & $1(4.2)$ & $5(5.8)$ & 0.7533 & $1(3.2)$ & $5(6.3)$ & 0.5191 \\
\hline $41-50$ & $5(4.5)$ & $0(0.0)$ & $5(5.8)$ & 0.2266 & $1(3.2)$ & $4(5.1)$ & 0.6772 \\
\hline $51-60$ & $6(5.5)$ & $2(8.3)$ & $4(4.7)$ & 0.4824 & $3(9.7)$ & $3(3.8)$ & 0.2218 \\
\hline $61-70$ & $7(6.4)$ & $3(12.5)$ & $4(4.7)$ & 0.1636 & $3(9.7)$ & $4(5.1)$ & 0.3724 \\
\hline$>71$ & $12(10.9)$ & $5(20.8)$ & $7(8.1)$ & 0.0777 & $6(19.4)$ & $6(7.6)$ & 0.0751 \\
\hline
\end{tabular}

* Italic number shown statistical significant values

all isolates were susceptible to carbapenems (ertapenem and imipenem, Table 4). Eighty-seven percent of the isolates were resistant to at least one antimicrobial agent, and $63.3 \%$ (70 isolates) were multidrug-resistant (MDR). MDR isolates were resistant to ampicillin (85.7\%), trimethoprim-sulfamethoxazole (84.3\%), ampicillin-sulbactam (77.1\%), piperacillin-tazobactam (77.1\%) and ciprofloxacin (70\%, Table 4). A total of 94.2\% (49/52 isolates) of FQ-resistant strains showed MDR-phenotype. A similar distribution of FQ-resistant isolates was found in the same at hospital as communityacquired infections, except for norfloxacin, which was

Table 4 Antibiotic and multidrug resistance of the UPEC's isolates, $\mathbf{n}(\%)$

\begin{tabular}{|c|c|c|c|c|c|c|c|c|}
\hline Antibiotics & $\begin{array}{l}\text { Total } \\
\text { isolates, } \\
n=110(\%)\end{array}$ & MDR, $n=70(\%)$ & Male, $n=24(\%)$ & Female, $n=86(\%)$ & ${ }^{*} p$ & $\begin{array}{l}\text { Hospital- } \\
\text { acquired, } \\
n=31(\%)\end{array}$ & $\begin{array}{l}\text { Community- } \\
\text { acquired, } n=79 \\
(\%)\end{array}$ & ${ }^{*} p$ \\
\hline Amikacin & $11(10.0)$ & $11(15.9)$ & $4(16.7)$ & $7(8.1)$ & & $1(3.2)$ & $10(12.7)$ & \\
\hline Gentamicin & $31(28.2)$ & $29(41.4)$ & $11(45.8)$ & $20(23.3)$ & 0.0297 & $10(32.3)$ & 21 (26.6) & \\
\hline Tobramycin & $21(19.1)$ & $21(30.0)$ & $10(41.7)$ & $11(12.8)$ & 0.0015 & $9(29.0)$ & $12(15.2)$ & \\
\hline Netilmicin & $6(5.5)$ & $5(7.1)$ & $2(8.3)$ & $4(4.7)$ & & $2(6.5)$ & $4(5.1)$ & \\
\hline Ampicillin & 78 (70.9) & $60(85.7)$ & $20(83.3)$ & $58(67.4)$ & & $24(77.4)$ & $54(68.4)$ & \\
\hline $\begin{array}{l}\text { Ampicillin-sulbac- } \\
\text { tam }\end{array}$ & $61(55.5)$ & $54(77.1)$ & $15(62.5)$ & 46 (53.5) & & $18(58.1)$ & $43(54.4)$ & \\
\hline $\begin{array}{l}\text { Amoxicillin-clavu- } \\
\text { lanic acid }\end{array}$ & 26 (23.6) & $23(32.9)$ & $5(20.8)$ & $21(24.4)$ & & $6(19.4)$ & $20(25.3)$ & \\
\hline $\begin{array}{l}\text { Piperacillin-tazo- } \\
\text { bactam }\end{array}$ & $61(55.5)$ & $54(77.1)$ & 15 (62.5) & $46(53.5)$ & & 18 (58.1) & $43(54.4)$ & \\
\hline Cefazolin & $46(41.8)$ & $45(64.3)$ & $15(62.5)$ & $31(36.0)$ & 0.0202 & $16(51.6)$ & $30(38.0)$ & \\
\hline Cefotaxime & 20 (18.2) & $20(28.6)$ & $5(20.8)$ & 15 (17.4) & & $6(19.4)$ & $14(17.7)$ & \\
\hline Ceftazidime & $27(24.5)$ & 27 (38.6) & $13(54.2)$ & 14 (16.3) & 0.0001 & 12 (38.7) & 15 (19.0) & 0.0306 \\
\hline Ceftriaxone & $30(27.3)$ & $30(42.9)$ & $14(58.3)$ & 16 (18.6) & 0.0001 & $13(41.9)$ & $17(21.5)$ & 0.0305 \\
\hline Cefepime & 29 (26.4) & $29(41.4)$ & $14(58.3)$ & 15 (17.4) & 0.0001 & 12 (38.7) & $17(21.5)$ & \\
\hline $\begin{array}{l}\text { Trimethoprim-sul- } \\
\text { famethoxazole }\end{array}$ & $80(72.7)$ & $59(84.3)$ & $18(75.0)$ & $62(72.1)$ & & $24(77.4)$ & $56(70.9)$ & \\
\hline Ciprofloxacin & $52(47.3)$ & $49(70.0)$ & 17 (70.8) & 35 (40.7) & 0.0089 & 15 (48.4) & $37(46.8)$ & \\
\hline Levofloxacin & 48 (43.6) & $45(64.3)$ & $16(66.7)$ & $32(37.2)$ & 0.0314 & $13(41.9)$ & $35(44.3)$ & \\
\hline Norfloxacin & 18 (16.4) & $18(25.7)$ & $3(12.5)$ & 15 (17.4) & & $2(6.5)$ & $16(20.3)$ & \\
\hline Nitrofurantoin & $14(12.7)$ & $12(17.1)$ & $5(20.8)$ & $9(10.5)$ & & $4(12.9)$ & $10(12.7)$ & 0.0002 \\
\hline Ertapenem & $0(0.0)$ & $0(0.0)$ & $0(0.0)$ & $0(0.0)$ & & $0(0.0)$ & $0(0.0)$ & \\
\hline Imipenem & $0(0.0)$ & $0(0.0)$ & $0(0.0)$ & $0(0.0)$ & & $0(0.0)$ & $0(0.0)$ & \\
\hline
\end{tabular}

* Only statistical significant values are shown 
higher among community-acquired infections $(20.3 \%$ vs 6.5\%, Table 4). Distribution of ciprofloxacin and levofloxacin resistance was significantly higher among male than female gender $(70.8,66.7 \%, p=0.0089,0.0314$ vs 40.7 , $37.2 \%$, respectively, Table 4 ).

Co-resistance phenotype between cephalosporins and beta-lactams towards fluoroquinolones was frequently observed [(amoxicillin-clavulanic acid $(p=0.0004)$, cefazolin $(p=0.0299)$, cefotaxime $(p=0.0001)$, ceftriaxone $(p=0.0002)$ and, cefepime $(p=0.0015)]$. Trimethoprim-sulfamethoxazole and cephalosporins [cefotaxime $(p=0.0232)$ and ceftazidime $(p=0.0001)]$ also showed a co-resistance.

Overall, hospital-acquired isolates were slightly more resistant than community-acquired isolates $(33.1 \%$ vs $28.7 \%$, respectively). Both hospital and communityacquired isolates showed higher resistance towards ampicillin (77.4\% vs $68.4 \%)$ and trimethoprim-sulfamethoxazole (77.4\% vs $70.9 \%)$. UPEC isolates from hospital-acquired infections were associated to ceftazidime $(p=0.0306)$, ceftriaxone $(p=0.0305)$, and nitrofurantoin $(p=0.0002)$ resistance phenotype (Table 4$)$. MDR-phenotype was equally distributed among community-acquired (64.5\%) and hospital-acquired (61.3\%) isolates. Moreover, MDR-phenotype was associated to male infections (83.33\%, $p=0.02329)$. MDR-phenotype (69.6\%) as well as the FQ-resistant phenotype $(69.6 \%, \mathrm{p}=0.0008)$ was also prevalent among older adults ( $>60$ years old).

\section{Phylogenetic characterization, virulence genes, and their association to MDR-phenotype}

All seven phylogenetic lineages (A, B1, B2, C, D, E and $\mathrm{F})$ and cryptic clades were found on the 110 urinary $E$. coli isolates. The phylo-groups D (23.6\%) and A (19.1\%) were the most commonly found, followed by B1 (15.5\%), C (13.6\%), B2 (11.8\%), F (10\%), cryptic clades (5.5\%) and phylo-group E (0.9\%). The different phylo-groups and cryptic clades were distributed in both hospital and community settings, except the phylo-group $E$ which was only distributed in the hospital-acquired infections. MDR strains were distributed into all phylogenetic-groups: $26 \%(16 / 70)$ to $\mathrm{A}, 17.1 \%(12 / 70)$ to $\mathrm{D}, 15.7 \%(11 / 70)$ to B1, $12.9 \%(9 / 70)$ to $C, 11.4 \%(8 / 70)$ to $\mathrm{B} 2$ and $\mathrm{F}$, and $6.7 \%$ (5/70) to cryptic clades. Phylo-group D was significantly associated to MDR-phenotype $(p=0.0339)$ as well as FQresistant phenotype $(26 \%, p=0.0173)$. Phylo-groups B2 and $\mathrm{D}$ were more common among community-acquired isolates $(18.2,9.1 \%)$ than hospital-acquired isolates $(5.5$, $2.7 \%)$, as well as in females (20.9, 7.3\%) than in males (4.5, $2.7 \%$ ) but not significantly associations were found.

Overall, fimH (71.8\%), fyuA (68.2\%), and agn43 (54.5\%) were the virulence genes with the highest distributions among isolates, while afa/dra (8.2\%) and cnf1 (2.7\%) had the lowest. Others virulence genes tested had the following distribution: chuA, 49.1\%; papC, 42.7\%; kpsMTII, 37.3\%; vat, 20\%; yfc V, 20\%; sfaS $10 \%$, and hlyA, 9.1\% (Table 5). Isolates from hospital-acquired infections presented slightly more prevalence of virulence genes than community-acquired infections ( $35.2 \%$ vs $30.2 \%)$. Prevalence of $f y u A$ ( $71.0 \%$ vs $67.1 \%)$, papC (48.4\% vs $40.5 \%)$, $y f c V(25.8 \%$ vs $55.7 \%), h l y A$ ( $12.9 \%$ vs $7.6 \%)$, cnfl $(3.2 \%$ vs $2.5 \%)$, kpsMTII (58.1\% vs $29.1 \%$ ) and chuA (51.6\% vs $48.1 \%$ ) were higher among UPEC isolated from hospitalacquired than community-acquired infections. However, only the kpsMTII was significantly associated with hospital-acquired isolates ( $58.1 \%$ vs $29.1 \%, p=0.0047$, Table 5$)$.

Table 5 Distribution of virulence genes among UPEC strains, $\mathbf{n}(\%)$

\begin{tabular}{|c|c|c|c|c|c|c|c|c|}
\hline Virulence genes & $\begin{array}{l}\text { Total } \\
\text { isolates, } \\
n=110(\%)\end{array}$ & MDR, $n=70(\%)$ & Male, $n=24$ (\%) & Female, $n=86(\%)$ & ${ }^{*} p$ & $\begin{array}{l}\text { Hospital- } \\
\text { acquired, } \\
n=31(\%)\end{array}$ & $\begin{array}{l}\text { Community- } \\
\text { acquired, } n=79 \\
(\%)\end{array}$ & ${ }^{*} p$ \\
\hline fyuA & $75(68.2)$ & $46(65.7)$ & $14(58.3)$ & $61(70.9)$ & & $22(71.0)$ & $53(67.1)$ & \\
\hline $\mathrm{fimH}$ & $79(71.8)$ & $51(72.9)$ & $20(83.3)$ & 59 (68.6) & & $21(67.7)$ & $58(73.4)$ & \\
\hline sfas & $11(10)$ & $6(8.6)$ & $2(8.3)$ & $9(10.5)$ & & $2(6.5)$ & $9(11.4)$ & \\
\hline$a f a / d r a$ & $9(8.2)$ & $5(7.1)$ & $0(0.0)$ & $9(10.5)$ & & $2(6.5)$ & $7(8.9)$ & \\
\hline papc & $47(42.7)$ & 27 (38.6) & $12(50.0)$ & $35(40.7)$ & & $15(48.4)$ & $32(40.5)$ & \\
\hline $\operatorname{agn} 43$ & $60(54.5)$ & $39(55.7)$ & $14(58.3)$ & $46(53.5)$ & & $16(51.6)$ & $44(55.7)$ & \\
\hline$y f c V$ & $22(20)$ & $15(21.4)$ & $10(41.7)$ & $12(14.0)$ & 0.0026 & $8(25.8)$ & $14(17.7)$ & \\
\hline vat & $22(20)$ & $13(18.3)$ & $7(29.2)$ & $15(17.4)$ & & $6(19.4)$ & $16(20.3)$ & \\
\hline hlyA & $10(9.1)$ & $7(10.0)$ & $4(16.7)$ & $6(7.0)$ & & $4(12.9)$ & $6(7.6)$ & \\
\hline cnfl & $3(2.7)$ & $2(2.9)$ & $1(4.2)$ & $2(2.3)$ & & $1(3.2)$ & $2(2.5)$ & \\
\hline kpsMTII & $41(37.3)$ & $25(35.7)$ & $9(37.5)$ & $32(37.2)$ & & $18(58.1)$ & $23(29.1)$ & 0.0047 \\
\hline chuA & $54(49.1)$ & $32(45.7)$ & $11(45.8)$ & $43(50.0)$ & & $16(51.6)$ & $38(48.1)$ & \\
\hline
\end{tabular}

* Only statistical significant values are shown 
Comparing male vs female patients, isolates from females had a higher mean of virulence genes compared those isolates from male origin ( $21.5 \%$ vs $7.9 \%$, respectively). Moreover, the $y f c V$ was significantly more associated to male infections $(41.7 \%, p=0.0026)$. The presence of the chuA gene was associated to UPEC isolated from children $(p=0.0483)$. Furthermore, the presence of vat was associated to UPEC isolates from adults $(p=0.0153)$.

Virulence genes fimH (72.9\%), fyuA (65.7\%), agn43 (55.7\%) and chuA (45.7\%, Table 5), were highly distributed among MDR strains. However none virulence genes were significantly associated to MDR-phenotype or FQ-resistant isolates. Nevertheless, fimH (69.2\%), fyuA (67.3\%) and chuA (57.7\%) were highly distributed among FQ-resistant bacteria.

\section{Identification of virulence, and antimicrobial resistance} genes by microarray analysis

Microarray analysis was done on $18 \mathrm{E}$. coli isolates belonging to the phylo-groups B2, D and F. Overall, 145 virulence and 40 antimicrobial resistance genes among the 315 and 82 genes and variants investigated were detected at least once in one or more of the isolates. The total number of virulence genes per isolate ranged from 18 to 63 genes. The median number of the virulence genes per isolate was 35 . Microarray hybridizations demonstrated that all the $E$. coli isolates tested possessed virulence genes related to a pathotype including ExPEC and diarrheagenic E. coli (DEC). The total number of antimicrobial resistance genes per isolate ranged from 0 to 21 genes with a median number of 6.5 genes. Since the microarray carries a large set of virulence factors, numerous incomplete ExPEC that would normally be missed in a PCR-based assay were found. Thus, various unusual gene combinations were discovered, such as ExPEC pathogenic profiles with assorted EPEC genes coding for the type III secretion system 2 proteins ErpJ and SpaS (gene eprJ and epaS, respectively). Moreover, detection of virulence (mean $39.0 \pm 16.9$ ) and antimicrobial resistance (mean $9.0 \pm 1.9$ ) genes were higher on hospital-acquired UTIs isolates compared to community-acquired infections (Table 6). Higher frequency of virulence genes was found among isolates retrieved from females compared to those from males $(36.25 \pm 17.04$

Table 6 Virulence and antimicrobial resistance genes detected by microarray analysis exclusively among E. coli B2, D and $\mathrm{F}$ isolates from $\mathrm{UTIs}$ patients

\begin{tabular}{|c|c|c|}
\hline & \multicolumn{2}{|l|}{ Type of infection } \\
\hline & Hospital-acquired $(n=4)$ & Community-acquired $(n=14)$ \\
\hline Virulence genes (mean) & 39 & 32 \\
\hline Antimicrobial resistance genes (mean) & 9 & 6 \\
\hline Phylo-groups & $\mathrm{B} 2(n=2)$ and $\mathrm{D}(n=2)$ & $\mathrm{B} 2(n=9), \mathrm{D}(n=3)$ and $\mathrm{F}(n=2)$ \\
\hline \multicolumn{3}{|l|}{ Virulence genes function } \\
\hline Resistance & 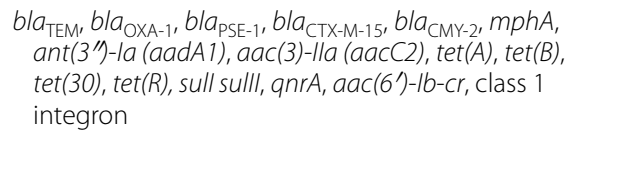 & 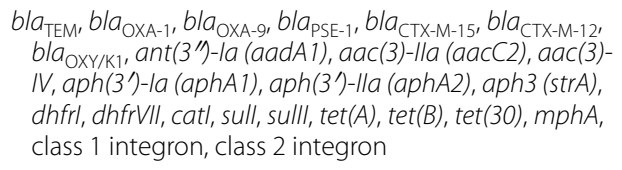 \\
\hline Adhesins & $\begin{array}{l}\text { afaD, afaD8, afaE1, afaE2, afaE5, bfpA, fimC, ibeB, csgA, } \\
\text { csgE, f165(1)A, fimA, fimH, iha, IpfA(O113), papA(10), } \\
\operatorname{papA}(11), \operatorname{papA}(16), \operatorname{papA}(8), \operatorname{papC}, \operatorname{papGl2,} \text { fitA, } \\
\text { sfaHII, sfaD }\end{array}$ & $\begin{array}{l}\text { afaE1, afaE2, afaE5, cofA, IpfA2, fimC, csgA, csgE, csuA, } \\
\text { F17b-A, F17d-A, facA, IpfA1, fimA, iha, IpfA(O113), } \\
\text { IpfA, papA(8), papA(9), papA(10), papA(12), papA(13), } \\
\text { papA(15), papA(40), papA(48), papC, papGll, papGIV, } \\
\text { fitA, sfaHII, sfaA }\end{array}$ \\
\hline Colcins and microsins & $c v a C, m c h B$ & cda, cela, cib, cvaC, mcbA. \\
\hline Toxins & Sat & $\operatorname{ast} A, \operatorname{ast} A(2), c d t B-4, c n f 1$, sat \\
\hline Iron acquisition or transport system & $\begin{array}{l}\text { chuA, fepC, fyuA, iroN, iroN(2), irp 1, irp2, iucD, iutA, } \\
\text { iutA(2), iutA(UPEC), sitA, sitD }\end{array}$ & $\begin{array}{l}\text { chuA, fepC, fimH, fyuA, iroN(2), irp 1, irp2, iucD, iutA, } \\
\text { iutA(2), iutA(UPEC), sitA, sitD }\end{array}$ \\
\hline Capsular and somatic antigens & kpsMTII, neuC & kpsMTII, neuA, neuC \\
\hline Locus of enterocyte effacement (LEE) & eae(delta) & eae(lambda), espG, esta1 \\
\hline ETT2 elements & eivG, epr」 & eivG, eprJ, epas \\
\hline Haemolysins and hemagglutinins & hlyA, hlyE, hral & bmaE, hlyA, hlyE, hra1. \\
\hline Various functions & $\begin{array}{l}\text { agn43, capU, ccdB, deoK, fliC, gad, iss, iss(3), malX, } \\
\text { ompA, ompT, ompT(2), senB, traT }\end{array}$ & $\begin{array}{l}\text { agn43, capU, ccdB, ibeA, ibeB, deoK, eaf, fliC, fliC (H7), gad, } \\
\text { invX, iss, iss(3), malX, ompA, ompT, ompT(2), senB, traT }\end{array}$ \\
\hline $\begin{array}{l}\text { Newly recognized or putative E. coli } \\
\text { virulence genes }\end{array}$ & arts, b1121, b1432, gimB(orf1), mviM, mviN, shf, usp, virk & arts, b1121, mviM, mviN, set, shf, usp, virk \\
\hline
\end{tabular}


mean vs $31.66 \pm 13.00$ mean, respectively), as well as those isolates from children vs adults $(36.58 \pm 7.4$ mean vs $26.6 \pm 16.39$ mean, respectively). In addition, antimicrobial resistance genes were also detected on higher ratios among isolates retrieved from males compared to those from females $(7.88 \pm 5.53$ mean vs $4.0 \pm 3.03$ mean, respectively); a similar situation was observed when strains isolates from children vs those from adults were compared ( $14.60 \pm 5.79$ mean vs $4.4 \pm 2.60$ mean, respectively). Interestingly, the maximum number of antimicrobial resistance genes was found among UPEC isolates from children.

\section{Distribution of plasmid-mediated quinolone resistance genes, and ESBL genes}

Overall, $22 \%$ of the isolates were positive for qnrA (25 isolates), $20.9 \%$ (23 isolates) to $q n r B, 6.4 \%$ (7 isolates) to $q n r S 1,0.9 \%$ ( 1 isolates) to $q n r C, 4.5 \%$ (5 isolates) to $q n r D$, and $6.4 \%$ (7 isolates) to $a a c\left(6^{\prime}\right)-I b-c r$ (Table 7). None isolates were positive to qepA gene. Isolates were taken to sequencing to obtain information on the QRDRs of the $g y r A$ and $\operatorname{par} C$ genes, respectively. The sequencing results for the QRDR of gyrA and parC are summarized in Table 8. Only one isolate tested had no mutations in the QRDRs of gyrA and parC since was sensitive to ciprofloxacin (CIP), levofloxacin (LEV), and norfloxacin (NOR). The double mutations in Ser-83 $\rightarrow$ Leu and Asp-87 $\rightarrow$ Tyr or Asp-87 $\rightarrow$ Asn substitution in gyrA were present in $92 \%$ of the strain tested. Ser- $80 \rightarrow$ Ile substitution in $\operatorname{parC}$ were found in $92 \%$ of the isolates tested, which also were resistant to both ciprofloxacin and levofloxacin. The substitution Thr-66 $\rightarrow$ Ser $(1$ strain, CIP-resistant, LEV-resistant), Thr-66 $\rightarrow$ Asn (1 strain, CIP-resistant, LEV-resistant), and Thr- $66 \rightarrow \mathrm{Tyr}$ (2 strains, CIP-resistant, LEV-resistant) were also found in parC. Other substitutions in parC as Glu- $84 \rightarrow$ Val $(2$ strains, CIP-resistant, LEV-resistant) and Glu-84 $\rightarrow$ Ala were also detected. Interestingly, one strain (isolated UEc
76) which was resistant to ciprofloxacin, levofloxacin and norfloxacin, belonging to $\mathrm{B} 2$ phylo-group and blaCTXM-containing, also carried the double mutations in Ser$83 \rightarrow$ Leu and Asp- $87 \rightarrow$ Asn substitution in $g y r A$ and the triple mutation in parC Ser- $80 \rightarrow$ Ile, Thr- $66 \rightarrow$ Tyr and Glu-84 $\rightarrow$ Val.

ESBL genes were investigated through microarray and PCR assay. A total of 27 isolates (24.5\%) suspected as cephalosporinase producers showed positive PCRs for $b l a_{\text {CTX-M }}\left(12.7 \% / 14\right.$ isolates), $b l a_{\mathrm{TEM}}(18.2 \% / 20$ isoaltes), $b l a_{\mathrm{PSE}}\left(2.7 \% / 3\right.$ isoaltes), and $b l a_{\mathrm{OXA}}$ (9.1\%/10 isolates). Sequencing of the $b l a_{\mathrm{CTX}-\mathrm{M}}$ amplicons identified the presence of $b l a_{\mathrm{CTX}-\mathrm{M}-15}$ in $7.2 \%$ of the strains (8 isolates), $b l a_{\mathrm{CTX}-\mathrm{M}-12}$ in $4.5 \%$ (5 isolates), $b l a_{\text {СТХ-M-3 }}$ in $1.8 \%$ (2 isolates), and $b l a_{\mathrm{CTX}-\mathrm{M}-14}$ in $1.8 \%$ (2 isolates). Furthermore, $b l a_{\mathrm{ROB}-1}, b l a_{\mathrm{SHV}-37}$, and $b l a_{\mathrm{CMY}-2}$ genes, were identified in one isolate $(0.9 \%)$ through the microarray assay.

Overall $b l a_{\text {CTX-M }}$ genes and PMQR genes as well as mutation in QRDR were found in both community- and hospital-acquired infections as well as in male and female genders. The PMQR qnrA (21.4\%), and qnrB (18.6\%), were highly distributed on MDR-phenotype (Table 7). Isolates from males had higher prevalence of $a a c\left(6^{\prime}\right)$ $I b$-cr gene compare to female isolates $(16.6 \%$ vs $3.5 \%$, $p=0.0194$ ). Quinolone-resistance isolates also presented higher prevalence to $b l a_{\text {CTX-M }}$ compared to quinolonesensitive phenotype isolates ( $21 \%$ vs $5.2 \%, p=0.012$ ).

\section{Discussion}

In accordance with global trends, our results reveal higher prevalence of urinary tract infections in female patients than in males [7,34-36]. The emergence of high rates of antibiotic resistance and MDR-phenotype from urinary tract infections related bacteria becomes a public health concern worldwide. In this study, more than $70 \%$ of the isolates showed resistance to trimethoprim-sulfamethoxazole (TMP-SXT) that is recommended as a first choice for UTI treatment [36]. Previous

Table 7 Distributions of PMQR and blaCTX-M genes among UPEC, $\mathbf{n}$ (\%)

\begin{tabular}{|c|c|c|c|c|c|c|c|}
\hline Virulence genes & $\begin{array}{l}\text { Total isolates, } \\
n=110(\%)\end{array}$ & MDR, $n=70(\%)$ & Male, $n=24(\%)$ & Female, $n=86(\%)$ & ${ }^{*} p$ & $\begin{array}{l}\text { Hospital- } \\
\text { acquired, } n=31 \\
(\%)\end{array}$ & $\begin{array}{l}\text { Community- } \\
\text { acquired, } n=79 \\
(\%)\end{array}$ \\
\hline qnrA & $25(22.7)$ & $15(21.4)$ & $7(29.2)$ & 18 (20.9) & & $9(29.0)$ & $16(20.3)$ \\
\hline$q n r B$ & $23(20.9)$ & 13 (18.6) & $6(25.0)$ & 17 (19.8) & & $10(32.3)$ & $13(16.5)$ \\
\hline anrs & $7(6.4)$ & $3(4.3)$ & $3(12.5)$ & $4(4.7)$ & & $2(6.5)$ & $5(6.3)$ \\
\hline anrC & $1(0.9)$ & $0(0.0)$ & $0(0.0)$ & $1(1.2)$ & & $0(0.0)$ & $1(1.3)$ \\
\hline anrD & $5(4.5)$ & $4(5.7)$ & $1(4.2)$ & $4(4.7)$ & & $3(9.7)$ & $2(2.5)$ \\
\hline $\operatorname{aac}\left(6^{\prime}\right)-1 b-c r$ & $7(6.4)$ & $4(5.7)$ & $4(16.6)$ & $3(3.5)$ & 0.0194 & $2(6.5)$ & $5(6.3)$ \\
\hline$b l a_{C T X-M}$ & $14(12.4)$ & $11(15.7)$ & $5(20.8)$ & $9(10.5)$ & & $4(12.9)$ & $10(12.7)$ \\
\hline
\end{tabular}

* Only statistical significant values are shown 
Table 8 Characterization of UTI isolates

\begin{tabular}{|c|c|c|c|c|c|c|c|c|}
\hline \multirow[t]{2}{*}{ Strain } & \multirow[t]{2}{*}{ Resistance profile } & \multirow[t]{2}{*}{ Phylo-group } & \multirow[t]{2}{*}{ PMQR genes } & \multicolumn{2}{|c|}{ QRDR mutations } & \multirow{2}{*}{$\begin{array}{l}\beta \text {-lactamase- } \\
\text { resistance-genes }\end{array}$} & \multirow{2}{*}{$\begin{array}{l}\text { Other resistant } \\
\text { genes }\end{array}$} & \multirow[t]{2}{*}{ Integron } \\
\hline & & & & $\Delta \mathrm{GyrA}$ & $\Delta$ ParC & & & \\
\hline UEC 11 & AMP, SXT & B2 & & NA & NA & $b l a_{\mathrm{TEM}}$ & $\begin{array}{l}\text { ant(3")-la (aadA1), } \\
\text { aph3 (strA), dhfrl, } \\
\text { sulll, tet(B) }\end{array}$ & Class 2 integron \\
\hline UEC 22 & $\begin{array}{l}\text { AMP, SAM, AMC, CFZ, } \\
\text { SXT, CIP, LEV, NOR }\end{array}$ & B2 & & $\begin{array}{l}\mathrm{S} 83 \rightarrow \mathrm{L} \\
\mathrm{D} 87 \rightarrow \mathrm{N}\end{array}$ & $\begin{array}{l}\mathrm{S} 80 \rightarrow 1 \\
\mathrm{~T} 66 \rightarrow \mathrm{N}\end{array}$ & $b l a_{\mathrm{TEM}}$ & $\operatorname{tet}(B)$ & \\
\hline UEC 23 & $\begin{array}{l}\text { AMP, SAM, CFZ, CTZ, } \\
\text { CAZ, CRO, FEP, SXT, } \\
\text { CIP, LEV }\end{array}$ & $\mathrm{F}$ & $a a c\left(6^{\prime}\right)-1 b-c r$ & NA & NA & & $\operatorname{aac}(3)-\| a(a a c C 2)$ & Class 1 integron \\
\hline UEc 27 & $\begin{array}{l}\text { GEN, AMP, SAM, } \\
\text { AMC, SXT, CIP, LEV }\end{array}$ & B2 & & $\begin{array}{l}\mathrm{S} 83 \rightarrow \mathrm{L} \\
\mathrm{D} 87 \rightarrow \mathrm{N}\end{array}$ & $\begin{array}{l}\mathrm{S} 80 \rightarrow \mathrm{I} \\
\mathrm{E} 84 \rightarrow \mathrm{V}\end{array}$ & $b / a_{\mathrm{PSE}-1}$ & sull, tet(A) & \\
\hline UEC 30 & GEN, SAM, AMC, SXT & B2 & & NA & NA & $b l a_{\mathrm{OXA}-1}$ & $\begin{array}{l}\text { ant }\left(3^{\prime \prime}\right) \text {-la (aadA1), } \\
\quad \text { tet( }(A), \operatorname{tet}(30), \text { tet }^{\circledR}, \\
\text { sull }\end{array}$ & Class 1 integron \\
\hline UEC 58 & AMP, SXT, CIP, LEV & B2 & & $\begin{array}{l}\mathrm{S} 83 \rightarrow \mathrm{L} \\
\mathrm{D} 87 \rightarrow \mathrm{N} \\
\mathrm{G} 114 \rightarrow \mathrm{S}\end{array}$ & $\mathrm{S} 80 \rightarrow \mathrm{I}$ & $b l a_{\mathrm{TEM}}$ & $\begin{array}{l}\text { dhfrVIII, sulll, tet(B), } \\
\text { aph3 }(\operatorname{str} A), m p h A\end{array}$ & \\
\hline UEc 65 & $\begin{array}{l}\text { AMP, CFZ, CAZ, CRO, } \\
\text { FEP, CIP, LEV }\end{array}$ & $\mathrm{D}$ & & $\begin{array}{l}\mathrm{S} 83 \rightarrow \mathrm{L} \\
\mathrm{D} 87 \rightarrow \mathrm{N} \\
\mathrm{G} 114 \rightarrow \mathrm{S}\end{array}$ & $\mathrm{S} 80 \rightarrow \mathrm{I}$ & $\begin{array}{l}\text { bla } \\
\text { blaX-M-15 } \\
\text { TEM }\end{array}$ & $\begin{array}{l}\operatorname{aac}(3)-\| l a(\operatorname{aac}(2), \\
\quad \operatorname{dhfrVII,} \text { mphA, sull, } \\
\text { tet(B) }\end{array}$ & Class 1 integron \\
\hline UEc 69 & AMP, SXT, NIT & B2 & qnrA & NA & NA & $b l a_{\mathrm{TEM}}$ & sulll & \\
\hline UEc 75 & $\begin{array}{l}\text { AMK, GEN, AMP, SAM, } \\
\text { AMC, TZP, CFZ, } \\
\text { CTX, CRO, FEPCIP, } \\
\text { LEV, NOR }\end{array}$ & B2 & gnrA & $\begin{array}{l}\mathrm{S} 83 \rightarrow \mathrm{L} \\
\mathrm{D} 87 \rightarrow \mathrm{N}\end{array}$ & $\begin{array}{l}\mathrm{S} 80 \rightarrow \mathrm{I} \\
\mathrm{T} 66 \rightarrow \mathrm{Y}\end{array}$ & $b l a_{\mathrm{OXY} / \mathrm{K} 1}, b a_{\mathrm{TEM}}$ & $\begin{array}{l}\operatorname{aac}(3)-\| l a(\operatorname{aac} C 2), \\
\text { aph(3')-la (aphA1), } \\
\text { aph(3')-Ila (aphA2), } \\
\text { aph3 (strA), sull, } \\
\text { sulll, tet(A), tet(B) }\end{array}$ & \\
\hline UEC 76 & $\begin{array}{l}\text { CFZ, CAZ, CRO, FEP, } \\
\quad \text { CIP, LEV }\end{array}$ & B2 & & $\begin{array}{l}\mathrm{S} 83 \rightarrow \mathrm{L} \\
\mathrm{D} 87 \rightarrow \mathrm{N}\end{array}$ & $\begin{array}{l}\mathrm{S} 80 \rightarrow \mathrm{I} \\
\mathrm{T} 66 \rightarrow \mathrm{Y} \\
\mathrm{E} 84 \rightarrow \mathrm{V}\end{array}$ & 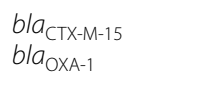 & $\operatorname{tet}(A), \operatorname{tet}(30)$ & \\
\hline UEc 84 & $\begin{array}{l}\text { GEN, TOB, AMP, SAM, } \\
\text { TZP, CFZ, CTX, CAZ, } \\
\text { CRO, FEP, SXT, CIP, } \\
\text { LEV }\end{array}$ & $\mathrm{D}$ & $a a c\left(6^{\prime}\right)-1 b-c r$ & $\begin{array}{l}\mathrm{S} 83 \rightarrow \mathrm{L} \\
\mathrm{D} 87 \rightarrow \mathrm{N}\end{array}$ & $\mathrm{S} 80 \rightarrow \mathrm{I}$ & $\begin{array}{l}\text { bla }_{\mathrm{CTX}-\mathrm{M}-15}, b l a_{\mathrm{OXA}-1} \\
\text { bla } \\
\text { bla }_{\mathrm{TEM}} \\
\text { PSE-4 }\end{array}$ & tet(30), mphA & \\
\hline UEC 99 & AMP, SXT & B2 & gnrA & None & None & $\begin{array}{l}\text { bla } a_{\mathrm{CTX}-\mathrm{M}-12} \\
b a_{\mathrm{OXA}-9}, b l a_{\mathrm{TEM}}\end{array}$ & $\begin{array}{l}\operatorname{aac}(3)-I V, a a c(3)-I l a \\
\text { (aacC2), aph3 } \\
\text { (strA), catl, sull, sulll }\end{array}$ & Class 1 integron \\
\hline UEC 102 & $\begin{array}{c}\text { AMP, CFZ, CAZ, CRO, } \\
\text { FEP, SXT, CIP, LEV }\end{array}$ & B2 & & $\begin{array}{l}\mathrm{S} 83 \rightarrow \mathrm{L} \\
\mathrm{D} 87 \rightarrow \mathrm{N} \\
\mathrm{G} 114 \rightarrow \mathrm{S}\end{array}$ & $\mathrm{S} 80 \rightarrow \mathrm{I}$ & $b l a_{\mathrm{TEM}}$ & $\begin{array}{l}\text { aph(3')-la (aphA1), } \\
\text { sulll }\end{array}$ & \\
\hline UEC 104 & AMP, SXT & $D$ & anrA, aac(6)-Ib-cr & NA & NA & $\begin{array}{l}\text { bla } a_{\mathrm{CMY}-2 \prime} \\
\text { bla } \\
\text { CTX-M-12, } \\
\text { bla } a_{\mathrm{OXA}-1}\end{array}$ & $\begin{array}{l}\operatorname{aac}(3)-\| l a(\operatorname{aac} C 2), \\
\text { sull, tet( }(B), m p h A\end{array}$ & Class 1 integron \\
\hline UEC 107 & & $\mathrm{~F}$ & & NA & NA & & & \\
\hline UEc 108 & AMP & $\mathrm{D}$ & gnrA & NA & NA & $b l a_{\mathrm{TEM}}$ & sull & Class 1 integron \\
\hline UEC 109 & AMP, SAM & $\mathrm{D}$ & $a a c\left(6^{\prime}\right)-1 b-c r$ & NA & NA & $b l a_{\mathrm{TEM}}$ & sulll & \\
\hline UEC 110 & $\begin{array}{l}\text { GEN, TOB, AMP, SAM, } \\
\text { CTX, SXT, CIP, NIT }\end{array}$ & B2 & & NA & NA & & $\begin{array}{l}\operatorname{aac}(3)-\| l a(a a c C 2), \\
\operatorname{tet}(B)\end{array}$ & Class 1 integron \\
\hline
\end{tabular}

AMK Amikacin, GEN gentamicin, TOB tobramycin, NET netilmicin, AMP ampicillin, SAM ampicillin-sulbactam, AMC amoxicillin-clavulanic acid, TZP piperacillintazobactam, CFZ cefazolin, CTX cefotaxime, CAZ ceftazidime, CRO ceftriaxone, FEP cefepime; SXT trimethoprim-sulfamethoxazole, CIP ciprofloxacin, $L E V$ levofloxacin, NOR norfloxacin, NIT nitrofurantoin, ETP ertapenem, IPM imipenem, PMQR plasmid-mediated quinolone resistance genes, QRDR quinolone resistance-determining region, NA not analyzed

studies reported similar results $[20,36]$. In agreement with Bouchillon et al. [34] in this study, UPEC isolates presented more than $40 \%$ resistance to ciprofloxacin and levofloxacin antibiotics. Moreover, resistance rates to antimicrobial drugs were higher in isolates from male than in those from female patients [37]. Interestingly, fluoroquinolones are widely used for the treatment of UTIs in male patients [36, 38]. It is possible that male infections may be more difficult to eradicate because of the higher rates of antibiotic resistance observed in 
strains isolated from males, which may lead to recurrent infections. These observations were similar to previous papers $[35,36,39]$. Susceptibility analysis of isolates to antibiotics prior to treatment choice is recommended.

Multidrug-resistant strain prevalence $(63.3 \%)$ was higher in this work than in other study from Mexico, which reported only $16.4 \%$ of MDR strains [21]. While work of Paniagua-Contreras et al. [20], showed 97\% of MDR strains. It is well known that susceptibility patterns may vary in different geographical regions and can be change over time [36]. In addition, an unexpected result was found, as the percentage of resistance to the antibiotics tested and MDR-phenotype were similar in hospital and community-acquired infections, indicating an important reservoir of resistance in both settings [34]. This could be due to household use of antibiotics before 2010, which would were acquired without prescription then. Moreover, resistance to cephalosporin and nitrofurantoin was associated to hospital-acquired infections. Co-resistance with fluoroquinolones and TMP-SXT was also observed in both hospital and community.

As detected by Ochoa et al. [21], phylo-group D, an important phylo-group in pathogenic ExPEC was associated to MDR-phenotype. Additionally, FQ-resistant strains were correlated to phylo-group D strains. Strains from hospital-acquired infections exhibited a greater number of virulence genes than those from community. In addition, E. coli isolates from hospital-acquired UTIs are correlated to the presence of kpsMTII gene that has been associated to pyelonephritis, a more severe infection of the upper urinary tract [40]. In agreement with other studies [20,41], our results showed an important frequency of $f y u A$-encoding yersiniabactin receptor and, fimH encoding type 1 fimbrial adhesion.

Detailed analysis of a strains subset using microarrays, revealed that some of them from both, hospital- and community-acquired infections carried virulence related genes of enteroaggregative and diffusely adherent $E$. coli (EAEC and DAEC), including capU (cap locus protein, hexosyltransferasa), deoK (deoxyribokinase), shf (putative virulence factor, plasmid pAA2, similar to Shigella flexneri Shf), virK (similar to Shigella flexneri virulence protein VirK, plasmid pAA2) and astA gene (EAEC heatstable enterotoxin 1). This was also reported in previous works [42-45], which noticed that EAEC virulence related genes were among the most frequent markers of diarrheagenic E. coli reported in ExPEC strains. The deoK operon is frequently associated with strains isolated from infected urine and blood and is part of a large genetic island carrying genes contributing to the strain intrinsic virulence and/or adaptive properties [43]. These strains, by acquiring the pAA plasmid, could become a potential diarrheal agent [42].
Another finding was the presence of enteropathogenic E. coli (EPEC) related genes on five UPEC isolates. These genes included the eae (coding for intimin, a protein involved in attaching and effacing lesions), as well as virulence related genes such as esp $G$ (protein secreted by the type III secretion system and translocated into host epithelial cells), eprJ (E. coli type III secretion system 2 protein ErpJ), epaS (E. coli type III secretion system 2 protein EpaS), and eivG (E. coli type III secretion system 2 protein EivG) [3, 46]. T3SS genes are not common in UPEC isolates, however genes encoding components of T3SS have been found $[47,48]$. These unusual gene combinations illustrate genome plasticity displayed by UPEC strains that may result in new hybrids pathotypes $[45,49$, 50].

In this study, UPEC strains carrying PMQR genes associated to quinolones resistance including qnrA, $q n r B$, $q n r S$, $q n r C$ and $q n r D$ as well as $a a c\left(6^{\prime}\right)-I b-c r$ were detected. The most common PMQR-genes identified were $q n r A$ and $q n r B$, which is in contrast to previous studies were $a a c\left(6^{\prime}\right)-I b$ - $c r$ gene detection was more frequent on ExPEC isolates [19, 51]. Moreover, qnrA and $q n r B$ were frequently found as a part of MDR-phenotype. $q n r D$ gene was found in $4.5 \%$ of the isolates. Previous papers reported $q n r D$ in bacteria isolated from rooks [51], pigs [15] and humans clinical isolates of Salmonella enterica serovar Kentucky, serovar Bovismorbificans, Proteus mirabilis and Morganella morganii [52, 53], as well as in E. coli from dogs [54]. In accordance to others studies [19, 55, 56], qepA was not identified. Although PMQR genes provide a low level of FQ-resistance, they have been reported to favor the selection of additional chromosome-encoded resistance mechanism [57]. In our study, QRDR mutations in gyrA and parC were prevalent in community-acquired infections ( $89 \%$ vs $11 \%)$. Overall, mutations in QRDR were equally present among isolates from males and females patients.

In our study, ESBL genes $b l a_{\mathrm{CTX-M}}\left(b l a_{\mathrm{CTX-M-15}}, b l a_{\mathrm{CTX}}\right.$ M-14, $b l a_{\mathrm{CTX}-\mathrm{M}-12}$, and $\left.b l a_{\mathrm{CTX}-\mathrm{M}-3}\right), b l a_{\mathrm{TEM}}, b l a_{\mathrm{PSE}}$, and $b l a_{\mathrm{OXA}}$ were detected. For the isolates carrying resistance genes, ESBL genes such as TEM, SHV and CTX-M, are the most widespread and frequently detected in E. coli [9]. In addition, CTX-M-15 is quite common in Mexico $[58,59]$.

\section{Conclusions}

Our study describes significant antimicrobial resistance in E. coli UTI isolates from hospital and community in Mexico. Diverse genotypes and phenotypes including multidrug-resistance, fluoroquinolone resistance and carriage of virulence genes related to several enteropathogenic $E$. coli were found among UPEC isolates. Thus, continuous surveillance for antimicrobial 
resistance of UPEC is needed in order to prevent treatment failure and to improve the strategies to mitigate the occurrence of antibiotic resistance organisms and ensure the best treatment to UTI patients. This study highlights the importance of antimicrobial resistance of virulent $E$. coli from urinary tract infection in Mexico.

\section{Abbreviations}

UTIs: urinary tract infections; MDR: multiple drug resistance; ExPEC: extraintestinal pathogenic E. coli; ESBL: extended-spectrum beta-lactamase; QRQR: quinolone resistance-determining region; FQ-phenotype: fluoroquinolone resistance phenotype.

\section{Authors' contributions}

All authors contributed towards the study concept, data analysis and revising of the paper and agreed to be accountable for all aspects of the work. All authors read and approved the final manuscript.

\begin{abstract}
Author details
${ }^{1}$ Laboratorio de Biología Celular y Tisular, Departamento de Morfología, Universidad Autónoma de Aguascalientes, Av. Universidad 940, Col. Cd. Universitaria, 20131 Aguascalientes, Mexico. ${ }^{2}$ Laboratorio de Ciencias Ambientales, Departamento de Fisiología y Farmacología, Universidad Autónoma de Aguascalientes, Av. Universidad 940, Col. Cd. Universitaria, 20131 Aguascalientes, Mexico. ${ }^{3}$ Departamento de Infectología, Centenario Hospital Miguel Hidalgo, Galeana Sur 495, Obraje, 20000 Aguascalientes, Mexico. ${ }^{4}$ Département de pathologie et microbiologie, Centre de Recherche en Infectologíe Porcine et Aviaire, Faculté de Médecine Vétérinaire, Université de Montréal, 3200, rue Sicott, Saint-Hyacinthe, Montreal, QC J2S 2M2, Canada.
\end{abstract}

\section{Acknowledgements}

We thank for the technical assistance to Fabiola Galindo Guerrero and Nayeli Amalinalli Pulido Hornedo. We also acknowledge the collaboration and help of the technician support of the clinical laboratory of the Centenario Hospital Miguel Hidalgo at Aguascalientes, Mexico. We thank to M.Sc. Philippe Garneau and Ph.D. Ricardo Oropeza for profiting the paper. We are thankful to Laboratoire de référence pour Escherichia coli $(\mathrm{ECL})$, of the Faculté de médecine vétérinaire of the Université de Montréal for kindly provide the controls for the phylo-group assay. We are gratefully acknowledge the fie grate support of the Natural Sciences and Engineering Research Council of Canada (RGPIN-25120) and from-Fonds de la recherché du Québec en Nature et Technologies (Centre de recherché en infectiologie porcine et avicole, CRIPA-Regroupements stratégiques RS-170946) to J. H. (RGPIN-25120) and from the DFAIT Canada's Emerging leaders in the Americas program. Authors contributed on this article are: Alma Lilian (AL) Guerrero Barrera; Flor Yazmín (FY) Ramírez Castillo; Adriana Cecilia (AC) Moreno Flores; Francisco Javier (FJ) Avelar González; Francisco (F) Márquez Díaz; Josée (J) Harel.

\section{Competing interests}

The authors declare that they have no competing interests.

\section{Availability of data and materials}

Not applicable.

\section{Consent for publication}

Not applicable.

\section{Ethics approval and consent to participate}

Not applicable.

\section{Funding}

Not applicable.

\section{Publisher's Note}

Springer Nature remains neutral with regard to jurisdictional claims in published maps and institutional affiliations.
Received: 6 April 2018 Accepted: 14 July 2018

Published online: 24 July 2018

\section{References}

1. Struelens MJ, Denis O, Rodriguez-Villalobos H. Microbiology of nosocomial infections: progress and challenges. Microbes Infect. 2004:6(11):1043-8

2. Kucheria R, Dasgupta P, Sacks SH, Khan MS, Sheerin NS. Urinary tract infections: new insights into a common problem. Postgrad Med J. 2005;81(952):83-6.

3. Kaper JB, Nataro JP, Mobley HL. Pathogenic Escherichia coli. Nat Rev Microbiol. 2004;2(2):123-40.

4. Stamm WE, Norrby SR. Urinary tract infections: disease panorama and challenges. J Infect Dis. 2001;183(Suppl 1):S1-4.

5. Russo TA, Johnson JR. Medical and economic impact of extraintestinal infections due to Escherichia coli: focus on an increasingly important endemic problem. Microbes Infect. 2003;5(5):449-56.

6. SINAVE/DGE/Salud. Boletín Epidemiológico. Sistema Nacional de Vigilancia Epidemiológica. Sistema Único de informaicón. Dirección General de Epidemiología. 2016;33(46):semana 46.

7. Dehbanipour R, Rastaghi S, Sedighi M, Maleki N, Faghri J. High prevalence of multidrug-resistance uropathogenic Escherichia coli strains, Isfahan, Iran. J Nat Sci Biol Med. 2016;7(1):22-6.

8. Liu BT, Yang QE, Li L, Sun J, Liao XP, Fang LX, Yang SS, Deng H, Liu YH. Dissemination and characterization of plasmids carrying oqXAB-bla $a_{\mathrm{CTX}-\mathrm{M}}$ genes in Escherichia coli isolates from food-producing animals. PLOS ONE. 2013:8(9):e73947.

9. Pitout JD, Laupland KB. Extended-spectrum beta-lactamase-producing Enterobacteriaceae: an emerging public-health concern. Lancet Infect Dis. 2008;8(3):159-66

10. Urban C, Mariano N, Bradford PA, Tuckman M, Segal-Maurer S, Wehbeh W, Grenner L, Colon-Urban R, Johnston B, Johnson JR, et al. Identification of CTX-M beta-lactamases in Escherichia coli from hospitalized patients and residents of long-term care facilities. Diagn Microbiol Infect Dis. 2010;66(4):402-6.

11. Martinez-Martinez L, Pascual A, Jacoby GA. Quinolone resistance from a transferable plasmid. Lancet. 1998;351(9105):797-9.

12. Robicsek A, Strahilevitz J, Sahm DF, Jacoby GA, Hooper DC. gnr prevalence in ceftazidime-resistant Enterobacteriaceae isolates from the United States. Antimicrob Agents Chemother. 2006;50(8):2872-4.

13. Perichon B, Courvalin P, Galimand M. Transferable resistance to aminoglycosides by methylation of G1405 in 16S rRNA and to hydrophilic fluoroquinolones by QepA-mediated efflux in Escherichia coli. Antimicrob Agents Chemother. 2007;51(7):2464-9.

14. Hansen LH, Johannesen E, Burmolle M, Sorensen AH, Sorensen SJ. Plasmid-encoded multidrug efflux pump conferring resistance to olaquindox in Escherichia coli. Antimicrob Agents Chemother. 2004;48(9):3332-7.

15. Zhao J, Chen Z, Chen S, Deng Y, Liu Y, Tian W, Huang X, Wu C, Sun Y, Sun $Y$, et al. Prevalence and dissemination of oqXAB in Escherichia coli isolates from animals, farmworkers, and the environment. Antimicrob Agents Chemother. 2010;54(10):4219-24.

16. Poirel L, Cattoir V, Nordmann P. Plasmid-mediated quinolone resistance; interactions between human, animal, and environmental ecologies. Front Microbiol. 2012;3:24.

17. Andres P, Lucero C, Soler-Bistue A, Guerriero L, Albornoz E, Tran T, Zorreguieta A, Group P, Galas M, Corso A, et al. Differential distribution of plasmid-mediated quinolone resistance genes in clinical enterobacteria with unusual phenotypes of quinolone susceptibility from Argentina. Antimicrob Agents Chemother. 2013;57(6):2467-75.

18. Amabile-Cuevas CF, Arredondo-Garcia JL, Cruz A, Rosas I. Fluoroquinolone resistance in clinical and environmental isolates of Escherichia coli in Mexico City. J Appl Microbiol. 2010;108(1):158-62.

19. Silva-Sanchez J, Cruz-Trujillo E, Barrios H, Reyna-Flores F, Sanchez-Perez A, Bacterial Resistance C, Garza-Ramos U. Characterization of plasmidmediated quinolone resistance (PMQR) genes in extended-spectrum beta-lactamase-producing Enterobacteriaceae pediatric clinical isolates in Mexico. PLoS ONE. 2013;8(10):e77968.

20. Paniagua-Contreras GL, Monroy-Perez E, Rodriguez-Moctezuma JR, Dominguez-Trejo P, Vaca-Paniagua F, Vaca S. Virulence factors, antibiotic 
resistance phenotypes and O-serogroups of Escherichia coli strains isolated from community-acquired urinary tract infection patients in Mexico. J Microbiol Immunol Infect. 2017;50(4):478-85.

21. Ochoa SA, Cruz-Cordova A, Luna-Pineda VM, Reyes-Grajeda JP, CazaresDominguez V, Escalona G, Sepulveda-Gonzalez ME, Lopez-Montiel F, Arellano-Galindo J, Lopez-Martinez B, et al. Multidrug- and extensively drug-resistant uropathogenic Escherichia coli clinical strains: phylogenetic groups widely associated with integrons maintain high genetic diversity. Front Microbiol. 2016:7:2042.

22. Sotto A, De Boever CM, Fabbro-Peray P, Gouby A, Sirot D, Jourdan J. Risk factors for antibiotic-resistant Escherichia coli isolated from hospitalized patients with urinary tract infections: a prospective study. J Clin Microbiol. 2001;39(2):438-44.

23. Standards NCCL, National Committee for Clinical Laboratory Standards. Performance standards for antimicrobial susceptibility testing; TwentySecond Informational Supplement: M100-S22. National Committee for Clinical Laboratory Standards: Wayne; 2012.

24. Clermont O, Christenson JK, Denamur E, Gordon DM. The Clermont Escherichia coli phylo-typing method revisited: improvement of specificity and detection of new phylo-groups. Environ Microbiol Rep. 2013;5(1):58-65.

25. Jacoby GA, Chow N, Waites KB. Prevalence of plasmid-mediated quinolone resistance. Antimicrob Agents Chemother. 2003;47(2):559-62.

26. Park CH, Robicsek A, Jacoby GA, Sahm D, Hooper DC. Prevalence in the United States of aac(6)-Ib-cr encoding a ciprofloxacin-modifying enzyme. Antimicrob Agents Chemother. 2006;50(11):3953-5.

27. Cavaco LM, Hasman $H$, Xia S, Aarestrup FM. qnrD, a novel gene conferring transferable quinolone resistance in Salmonella enterica serovar Kentucky and Bovismorbificans strains of human origin. Antimicrob Agents Chemother. 2009;53(2):603-8.

28. Wang M, Guo Q, Xu X, Wang X, Ye X, Wu S, Hooper DC, Wang M. New plasmid-mediated quinolone resistance gene, gnrC, found in a clinical isolate of Proteus mirabilis. Antimicrob Agents Chemother. 2009;53(5):1892-7.

29. Namboodiri SS, Opintan JA, Lijek RS, Newman MJ, Okeke IN. Quinolone resistance in Escherichia coli from Accra Ghana. BMC Microbiol. 2011;11:44.

30. Maynard C, Fairbrother JM, Bekal S, Sanschagrin F, Levesque RC, Brousseau R, Masson L, Lariviere S, Harel J. Antimicrobial resistance genes in enterotoxigenic Escherichia coli 0149:K91 isolates obtained over a 23-year period from pigs. Antimicrob Agents Chemother. 2003;47(10):3214-21.

31. Jakobsen L, Garneau P, Kurbasic A, Bruant G, Stegger M, Harel J, Jensen KS, Brousseau R, Hammerum AM, Frimodt-Moller N. Microarray-based detection of extended virulence and antimicrobial resistance gene profiles in phylogroup B2 Escherichia coli of human, meat and animal origin. J Med Microbiol. 2011:60(10):1502-11.

32. Bruant G, Maynard C, Bekal S, Gaucher I, Masson L, Brousseau R, Harell J. Development and validation of an oligonucleotide microarray for detection of multiple virulence and antimicrobial resistance genes in Escherichia coli. Appl Environ Microbiol. 2006;72(5):3780-4.

33. Bonnet C, Diarrassouba F, Brousseau R, Masson L, Topp E, Diarra MS. Pathotype and antibiotic resistance gene distributions of Escherichia coli isolates from broiler chickens raised on antimicrobial-supplemented Diets. Appl Environ Microbiol. 2009;75(22):6955-62.

34. Bouchillon S, Hoban DJ, Badal R, Hawser S. Fluoroquinolone resistance among gram-negative urinary tract pathogens: global smart program results, 2009-2010. Open Microbiol J. 2012;6:74-8.

35. Tabasi M, Asadi Karam MR, Habibi M, Yekaninejad MS, Bouzari S. Phenotypic assays to determine virulence factors of uropathogenic Escherichia coli (UPEC) isolates and their correlation with antibiotic resistance rattern. Osong Public Health Res Perspect. 2015;6(4):261-8.

36. Ali I, Rafaque S, Ahmed S, Malik JI, Dasti P. Prevalence of multi-drug resistant uropathogenic Escherichia coli in Potohar region of Pakistan. Asian Pac J Trop Biomed. 2016;6(1):60-6.

37. Linhares I, Raposo T, Rodrigues A, Almeida A. Frequency and antimicrobial resistance patterns of bacteria implicated in community urinary tract infections: a ten-year surveillance study (2000-2009). BMC Infect Dis. 2013:13:19.

38. Wagenlehner FM, Weidner W, Naber KG. Therapy for prostatitis, with emphasis on bacterial prostatitis. Expert Opin Pharmacother. 2007;8(11):1667-74.
39. Ibrahim ME, Bilal NE, Hamid ME. Increased multi-drug resistant Escherichia coli from hospitals in Khartoum state, Sudan. Afr Health Sci. 2012:12(3):368-75.

40. Lavigne JP, Bruyere F, Bernard L, Combescure C, Ronco E, Lanotte P, Coloby P, Thibault M, Cariou G, Desplaces N, et al. Resistance and virulence potential of uropathogenic Escherichia coli strains isolated from patients hospitalized in urology departments: a French prospective multicentre study. J Med Microbiol. 2016;65(6):530-7.

41. Tarchouna M, Ferjani A, Ben-Selma W, Boukadida J. Distribution of uropathogenic virulence genes in Escherichia coli isolated from patients with urinary tract infection. Int J Infect Dis. 2013;17(6):e450-3.

42. Abe CM, Salvador FA, Falsetti IN, Vieira MA, Blanco J, Blanco JE, Blanco M, Machado AM, Elias WP, Hernandes RT, et al. Uropathogenic Escherichia coli (UPEC) strains may carry virulence properties of diarrhoeagenic E. coli. FEMS Immunol Med Microbiol. 2008:52(3):397-406.

43. Martinez-Jehanne V, Pichon C, du Merle L, Poupel O, Cayet N, Bouchier C, Le Bouguenec C. Role of the vpe carbohydrate permease in Escherichia coli urovirulence and fitness in vivo. Infect Immun. 2012;80(8):2655-66.

44. Toval F, Kohler CD, Vogel U, Wagenlehner F, Mellmann A, Fruth A, Schmidt MA, Karch H, Bielaszewska M, Dobrindt U. Characterization of Escherichia coli isolates from hospital inpatients or outpatients with urinary tract infection. J Clin Microbiol. 2014;52(2):407-18.

45. Lara FB, Nery DR, de Oliveira PM, Araujo ML, Carvalho FR, Messias-Silva LC, Ferreira LB, Faria-Junior C, Pereira AL. Virulence markers and phylogenetic analysis of Escherichia coli strains with hybrid EAEC/UPEC genotypes recovered from sporadic cases of extraintestinal infections. Front Microbiol. 2017:8:146.

46. Zhou M, Guo Z, Duan Q, Hardwidge PR, Zhu G. Escherichia coli type III secretion system 2: a new kind of T3SS? Vet Res. 2014;45:32.

47. Miyazaki J, Ba-Thein W, Kumao T, Akaza H, Hayashi H. Identification of a type III secretion system in uropathogenic Escherichia coli. FEMS Microbiol Lett. 2002;212(2):221-8.

48. Subashchandrabose S, Hazen TH, Rasko DA, Mobley HL. Draft genome sequences of five recent human uropathogenic Escherichia coli isolates. Pathog Dis. 2013;69(1):66-70.

49. Bekal S, Brousseau R, Masson L, Prefontaine G, Fairbrother J, Harel J. Rapid identification of Escherichia coli pathotypes by virulence gene detection with DNA microarrays. J Clin Microbiol. 2003;41(5):2113-25.

50. Hamelin K, Bruant G, El-Shaarawi A, Hill S, Edge TA, Bekal S, Fairbrother JM, Harel J, Maynard C, Masson L, et al. A virulence and antimicrobial resistance DNA microarray detects a high frequency of virulence genes in Escherichia coli isolates from Great Lakes recreational waters. Appl Environ Microbiol. 2006;72(6):4200-6.

51. Röderova M, Halova D, Papousek I, Dolejska M, Masarikova M, Hanulik V, Pudova V, Broz P, Htoutou-Sedlakova M, Sauer P, et al. Characteristics of quinolone resistance in Escherichia coli isolates from humans, animals, and the environment in the Czech Republic. Front Microbiol. 2016;7:2147.

52. Seija V, Medina-Presentado JC, Bado I, Papa-Ezdra R, Batista N, Gutierrez C, Guirado M, Vidal M, Nin M, Vignoli R. Sepsis caused by New Delhi metallo$\beta$-lactamase (blaNDM-1) and qnrD-producing Morganella morganii, treated successfully with fosfomycin and meropenem: case report and literature review. Int J Infect Dis. 2015;30:20-6.

53. Szabó O, Gulyás D, Szabó N, Kristóf K, Kocsis B, Szabó D. Plasmid-mediated quinolone resistance determinants in Enterobacteriaceae from urine clinical samples. Acta Microbiol Immunol Hung. 2018;23:1-11.

54. Liu X, Liu H, Li Y, Hao C. High prevalence of $\beta$-lactamase and plasmidmediated quinolone resistance genes in extended-spectrum cephalosporin-resistant Escherichia coli from Dogs in Shaanxi, China. Front Microbiol. 2016;16(7):1843.

55. Garcia-Fulgueiras V, Bado I, Mota MI, Robino L, Cordeiro NF, Varela A, Algorta G, Gutkind G, Ayala JA, Vignoli R. Extended-spectrum betalactamases and plasmid-mediated quinolone resistance in enterobacterial clinical isolates in the paediatric hospital of Uruguay. J Antimicrob Chemother. 2011;66(8):1725-9.

56. Han C, Yang Y, Wang M, Wang A, Lu Q, Xu X, Wang C, Liu L, Deng Q, Shen $X$. The prevalence of plasmid-mediated quinolone resistance determinants among clinical isolates of ESBL or AmpC-producing Escherichia coli from Chinese pediatric patients. Microbiol Immunol. 2010;54(3):123-8.

57. Wang M, Tran JH, Jacoby GA, Zhang Y, Wang F, Hooper DC. Plasmidmediated quinolone resistance in clinical isolates of Escherichia coli from Shanghai, China. Antimicrob Agents Chemother. 2003;47(7):2242-8. 
58. Garza-Gonzalez E, Mendoza Ibarra SI, Llaca-Diaz JM, Gonzalez GM Molecular characterization and antimicrobial susceptibility of extendedspectrum \{beta\}-lactamase-producing Enterobacteriaceae isolates at a tertiary-care centre in Monterrey, Mexico. J Med Microbiol. 2011;60(Pt 1):84-90.

59. Merida-Vieyra J, De Colsa A, Calderon Castaneda Y, Arzate Barbosa P, Aquino Andrade A. First report of froup CTX-M-9 extended spectrum beta-lactamases in Escherichia coli isolates from pediatric patients in Mexico. PLoS ONE. 2016:11(12):e0168608.

60. Ramirez Castillo FY, Avelar Gonzalez FJ, Garneau P, Marquez Diaz F, Guerrero Barrera AL, Harel J. Presence of multi-drug resistant pathogenic Escherichia coli in the San Pedro River located in the State of Aguascalientes, Mexico. Front Microbiol. 2013:4:147.

61. Blanco M, Blanco JE, Alonso MP, Mora A, Balsalobre C, Munoa F, Juarez A, Blanco J. Detection of pap, sfa and afa adhesin-encoding operons in uropathogenic Escherichia coli strains: relationship with expression of adhesins and production of toxins. Res Microbiol. 1997;148(9):745-55.

62. Johnson JR, Stell AL. Extended virulence genotypes of Escherichia coli strains from patients with urosepsis in relation to phylogeny and host compromise. J Infect Dis. 2000;181(1):261-72.
63. Spurbeck RR, Dinh PC Jr, Walk ST, Stapleton AE, Hooton TM, Nolan LK, Kim KS, Johnson JR, Mobley HL. Escherichia coli isolates that carry vat, fyuA, chuA, and yfc $V$ efficiently colonize the urinary tract. Infect Immun. 2012;80(12):4115-22.

64. Wang H, Dzink-Fox JL, Chen M, Levy SB. Genetic characterization of highly fluoroquinolone-resistant clinical Escherichia coli strains from China: role of acrR mutations. Antimicrob Agents Chemother. 2001:45(5):1515-21.

65. Deguchi T, Yasuda M, Nakano M, Ozeki S, Kanematsu E, Nishino Y, Ishihara $\mathrm{S}$, Kawada Y. Detection of mutations in the gyrA and parC genes in quinolone-resistant clinical isolates of Enterobacter cloacae. J Antimicrob Chemother. 1997:40(4):543-9.

66. Maynard C, Bekal S, Sanschagrin F, Levesque RC, Brousseau R, Masson $L$, Lariviere S, Harel J. Heterogeneity among virulence and antimicrobial resistance gene profiles of extraintestinal Escherichia coli isolates of animal and human origin. J Clin Microbiol. 2004;42(12):5444-52.

67. Cattoir V, Poirel L, Nordmann P. Plasmid-mediated quinolone resistance pump QepA2 in an Escherichia coli isolate from France. Antimicrob Agents Chemother. 2008:52(10):3801-4.
Ready to submit your research? Choose BMC and benefit from:

- fast, convenient online submission

- thorough peer review by experienced researchers in your field

- rapid publication on acceptance

- support for research data, including large and complex data types

- gold Open Access which fosters wider collaboration and increased citations

- maximum visibility for your research: over $100 \mathrm{M}$ website views per year

At BMC, research is always in progress.

Learn more biomedcentral.com/submissions 